\title{
Case Study of Role of Pippalyadi Basti on Medoroga w.s.r.t. Obesity
}

\author{
DR. RITU WADHWA ${ }^{\mathbf{1}^{*}}$, M.D. Kayachikitsa ${ }^{2}$ \\ professor. Panchkarma, D.Y.Patil School Of Ayurveda, Nerul, Navi Mumbai
}

*Corresponding Author: Dr. Ritu Wadhwa, professor. Panchkarma, D.Y.Patil School Of Ayurveda, Nerul, Navi Mumbai

\begin{abstract}
To assess the effect of Pippalyadi Basti on Medoroga, 20 patients are enrolled for weight reduction through samshodhan therapy,out of these patients one case was found very interesting . Patient was having dementia \& weight gain problem. To manage weight two sittings of Pippalyadi Basti for 9 days was designed in the interval of 18 days, during interval period Pratimarsh Nasya was adviced for the management of Dementia. Assessment of therapy was done on subjective \& objective parameters. Satisfactiry result was found on both parameters.
\end{abstract}

Keywords: Pippalyadi8 Basti, Medoroga, Samshodhan Therapy, Pratimarsh Nasya.

\section{INTRODUCTION}

In Ayurveda, Medoroga is considered as excess fat deposition \& in modern parlance it is co-related to overweight/ obesity. Acharya Charak had described Atisthula person as most undesirable constitution in sutra sthan chapter 21. According to Carak, apart from the genetic factors, diet (like shleshmakar, abhishayandi) \& lifestyle (like avyayam, divaswapna) are the main contributing factors in the aetio pathogenesis of Medoroga. ${ }^{1}$

The management of obesity with modern drugs is quite unsatisfactory as most of the modern drugs employed in the treatment of the obesity possess serious side and toxic effects therefore it is decided to do Shodhan chikitsa in the form of Pippalyadi Basti. Pippalyadibasti2 is taken as ruksha tikshana basti which is advocated by Acharya Charak, and beneficial for Shleshmvikar.

Internal purification procedure like Pippalyadi basti do the strotas shodhan, sampraptivighatan \& is found to be effective in the reduction of body weight \& other associated complaints of obesity. Weight loss with help of shodan chikitsa is not a difficult task but to maintain that reduced weight is difficult. Pathay, Apathay was explained as Nidan Parivarjan for maintaining that reduced weight.

\section{CASE History}

A Female age 46 years visited Panchakarma O.P.D. D.Y. Patil Ayurveda Hospital, Nerul, NaviMumbai on 17/03/2019 for weight reduction as because of bharvrudhdhi she was having Backache \& bilateral knee joint pain. Her associate symptoms were aalasya, breathing difficulty while climbing, profuse sweating \& kshudha aadhikya. One unusual symptom was noticed while taking history she was having memory problems \& often forget her daily routine activity that hampers her routine work. She was having difficulty to recognise her relatives \& gradual memory loss was observed by the family members.

\section{Ashtavidha pariksha:}

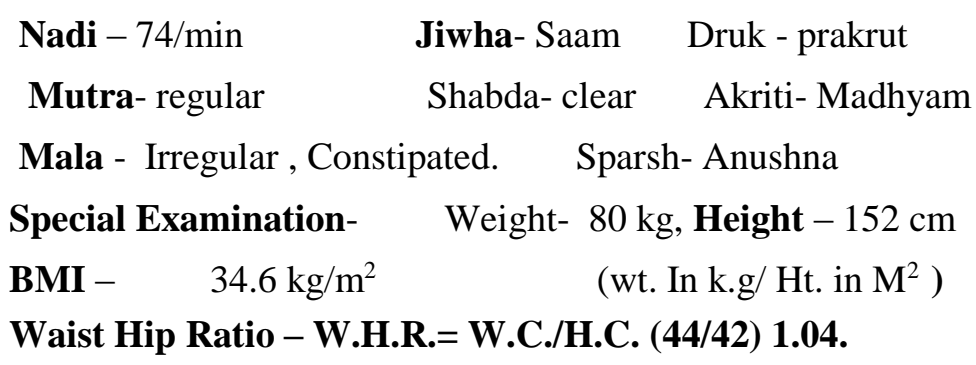




\section{ASSESSMENT CRITERIA:}

The assessment of overall effect of the therapy was based on the following gradings --

Subjective parameters-Clinical symptoms of the patient as described in CharakSamhita(ca. su. 21/4) ${ }^{3}$

- UtsahaHani / Aalasya

- Atikshudha

- Atipipasa

- Atisweda

- Dourbalya

- Dourgandhya

\begin{tabular}{|c|c|c|}
\hline Subjective Parameter & Observations & Scale \\
\hline \multirow[t]{5}{*}{ 1. Alasya/ utsahahani } & $\begin{array}{l}\text { No alasya (doing work } \\
\text { satisfactorily with proper vigor in } \\
\text { time) }\end{array}$ & Grade 0 \\
\hline & $\begin{array}{l}\text { Doing work satisfactorily with late } \\
\text { initiation }\end{array}$ & Grade I \\
\hline & $\begin{array}{l}\text { Doing work unsatisfactorily under } \\
\text { mental pressure and takes time }\end{array}$ & Grade II \\
\hline & $\begin{array}{l}\text { Not starting work on his } \\
\text { responsibility and doing little } \\
\text { work very slowly }\end{array}$ & Grade III \\
\hline & $\begin{array}{l}\text { Does not take any initiation not } \\
\text { want to work even after pressure }\end{array}$ & Grade IV \\
\hline \multirow{5}{*}{$\begin{array}{l}\text { 2. Atikshudha - (on the basis of } \\
\text { aharmatra) }\end{array}$} & Normal appetite $2-3$ times daily & Grade 0 \\
\hline & Excess appetite 2-3 times daily & Grade I \\
\hline & 3-4 times daily & Grade II \\
\hline & $4-5$ times daily & Grade III \\
\hline & More than 5times daily & Grade IV \\
\hline \multirow[t]{5}{*}{ 3. Atipipasa } & Normal thirst & Grade 0 \\
\hline & Upto 1 liter excess intake of water & Grade I \\
\hline & 1to 2 liter excess intake of water & Grade II \\
\hline & 2-3 liter excess intake of water & Grade III \\
\hline & More than 3liter intake of water & Grade IV \\
\hline \multirow[t]{5}{*}{ 4. Atisweda } & $\begin{array}{l}\text { Sweating after heavy work and fast } \\
\text { movement or in hot season }\end{array}$ & Grade 0 \\
\hline & $\begin{array}{l}\text { Profuse sweating after moderate } \\
\text { work and movement }\end{array}$ & Grade I \\
\hline & $\begin{array}{l}\begin{array}{l}\text { Sweating after little work and } \\
\text { movement }\end{array} \\
\end{array}$ & Grade II \\
\hline & $\begin{array}{l}\text { Profuse Sweating after little work } \\
\text { and movement }\end{array}$ & Grade III \\
\hline & $\begin{array}{l}\text { Sweating even at rest or in cold } \\
\text { season }\end{array}$ & Grade IV \\
\hline \multirow[t]{5}{*}{ 5. Daurbalya / Alpavyayam } & Can do routine exercise & Grade 0 \\
\hline & $\begin{array}{l}\text { Can do moderate exercise without } \\
\text { difficulty }\end{array}$ & Grade I \\
\hline & Can do only mild exercise & Grade II \\
\hline & $\begin{array}{lrrr}\begin{array}{l}\text { Can do mild } \\
\text { difficulty }\end{array} & \text { exercise } & \text { very } \\
\end{array}$ & Grade III \\
\hline & Cannot do even mild exercise & Grade IV \\
\hline \multirow[t]{4}{*}{ 6. Daurgandhya } & Absence of bad smell & Grade 0 \\
\hline & $\begin{array}{l}\text { Occasional bad smell from the } \\
\text { body which removed after bathing }\end{array}$ & Grade I \\
\hline & $\begin{array}{l}\text { Persistent bad smell limited to } \\
\text { close areas difficult to suppress } \\
\text { with deodorants. }\end{array}$ & Grade II \\
\hline & $\begin{array}{l}\text { Persistent bad smell felt from long } \\
\text { distance and is not suppressed by } \\
\text { deodorants. }\end{array}$ & Grade III \\
\hline
\end{tabular}




\begin{tabular}{|l|l|l|}
\hline & $\begin{array}{l}\text { Persistent bad smell felt from long } \\
\text { distance even tolerable to the } \\
\text { patient himself. }\end{array}$ & Grade IV \\
\hline
\end{tabular}

\section{Objective Parameters}

- $\quad$ Body weight

- Waist - Hip ratio $(\leq 0.8$ in Women $\& \leq 1$ in Men.)

- $\quad$ BMI ((BMI or Quetelet's Index) BMI=Weight in $\mathrm{kg} /$ Height in meter2

According to the BMI, patients can be divided into different degrees of obesity as follow: BMI classification:
1. Overweight: $25-29.9 \mathrm{~kg} / \mathrm{m}^{2}$
2. Obesity (Class I): $30-34.9 \mathrm{~kg} / \mathrm{m}^{2}$
3. Obesity (Class II): $35-39.9 \mathrm{~kg} / \mathrm{m}^{2}$
4. Obesity (ClassIII or morbid obesity): $>40 \mathrm{~kg} / \mathrm{m}^{2}$.

\section{Laboratory investigations}

Complete blood count includes CBC \&ESR, SERUM T3 \& T4 \& TSH, BLOOD SUGAR FASTING $\&$ POST PRANDIAL, BLOOD LIPID PROFILE.

Lab. Reports were found Normal. Her BMI was 34.6 which comes under classI Obesity.

\section{Material \& Methods}

Pippalyadi Basti was given in following manner

Two course of Basti for 9 days. As said by Acharya Charak Parihar kaal of basti should be twice of Basti course, hence after 18 days' interval second course of Pippalyadi Basti was repeated. Last followup was taken after second parihar kaal. Pippalyadi Bati is type of ruksha, tikshna Niruha Basti therefore followed by Trifaladi Anuwasan Basti.

\section{Material / Drugs of PippalyadiBasti:}

\begin{tabular}{|l|l|}
\hline \multicolumn{1}{|c|}{ Drugs } & Quantity \\
\hline Madhu & $80 \mathrm{gm}$ \\
\hline Yavakshar & $5 \mathrm{gm}$ \\
\hline Saindhva & $5 \mathrm{gm}$ \\
\hline Triphalataila & $50 \mathrm{ml}$ \\
\hline Kalka (Shatpushpachurna) & $20 \mathrm{gm}$ \\
\hline Gomutra & $80 \mathrm{ml}$ \\
\hline Kwath (Pippali ,Chitrak) & $320 \mathrm{ml}$ \\
\hline
\end{tabular}

Consecutive Niruhabasti(PippalyadiBasti )for 3 days andAnuvasan was given with triphala tail (100ml) on first day, fourth day and again 3 Niruh\& last dayAnuwasan was given..

\section{Duration and doses:}

\begin{tabular}{|l|l|}
\hline Drug & $\begin{array}{l}\text { Niruha- Pippaliadiniruhabasti\&LekhanBasti. (no. of } \\
\text { basti 6) } \\
\text { Anuvasan with triphala tail.(no. of basti 3) } \\
\text { SthanikSnehan with til oil and SthanikSwedan with } \\
\text { TriphalakwathNadiSweda }\end{array}$ \\
\hline Dose & $\begin{array}{l}\text { Niruha }-560 \mathrm{ml} \\
\text { Anuvasan- } 100 \mathrm{ml}\end{array}$ \\
\hline Kal & $\begin{array}{l}\text { Niruha- abhukta } \\
\text { Anuvasan- adrapaninambhojan (immediately after } \\
\text { meals) }\end{array}$ \\
\hline Duration & $\begin{array}{l}\text { Basti karma- } \\
\text { D1, D5\& D 9- Anuvasanbasti. }\end{array}$ \\
& $\begin{array}{l}\text { D2,D3D4,then D6,D7\&D8 means 3 } \\
\text { ContinuesNiruhabasti. }\end{array}$ \\
\hline Follow up & $0,10^{\text {th }}, 28^{\text {th }}, 38^{\text {th }}$ and $56^{\text {th }}$ day $(8$ weeks) \\
\hline
\end{tabular}




\section{ObServation \& ReSult}

It was observed that with the help of Basti Patient has reduced $11 \mathrm{k.g}$. weight in two months,apart from this, patient got significant result in subjective parameters.During the interval of Basti course Pratimarsh nasya with Jyotishmati oil was adviced, that helped in loss of Memory symptom.Overall result after Clinical Evaluation has revealed as follows -

Clinical Evaluation was done on the basis of grading of symptoms.

\begin{tabular}{|l|l|l|}
\hline Visit Symptoms & Before Treatment & After Treatment \\
\hline Alasya/utsah hani & Grade II & Grade I \\
\hline Ati kshudha & Grade III & Grade I \\
\hline Ati pipasa & Grade I & Grade 0 \\
\hline Ati sweda & Grade III & Grade I \\
\hline Shwasakrchrata & Grade II & Grade I \\
\hline Daurbalya & Grade I & Grade O \\
\hline Daurgandhya & Grade I & Grade0 \\
\hline Bharvriddhi & $80 \mathrm{~kg}$ & $69 \mathrm{~kg}$ \\
\hline
\end{tabular}

\section{DISCUSSION}

Medoroga (Obesity) is one among the major diseases that falls under the category of santarpanottha vyadhies4. This condition can lead to the association of many other disorders in its course. Hence, it gains high significance from the medical point of view.

Acharya Charak has described Ardhashlokokta Basti in siddhisthan chapter 10, 3 types of Vata, Pitta \& Shaleshma Har Basti, Pippalyadi Basti is one of them that is indicated as ShleshmaRogeshu Hiteshu. Keeping this point in the mind here this Basti is used in Obesity. Qualities of Triphaladitaila which is used as AnuvasanBasti in this patient mentioned in Sthoulyadhikara by Chakradatta5. Information regarding the Obesity on bases of BMI is considered from the contemporary science6. Probable action of Pippalyadi Basti is on the bases of its ingradients which are virudha guna of shleshma, that removes the obstruction \& deplete fat, because of that vata anuloman occurs, works as Tikshna agni upashaya, other channels get cleared \& nourishment of all dhatu . In this manner Sampraptivighatan of Medoroga (obesity) takes place.

\section{CONCLuSion}

On the bases of subjective \& objective parameters It is concluded that Pippalyadi Basti has significant role in the management of Medoroga. In this patient before treatment BMI was 34.6 (classI Obesity) after treatment it was 29.8(over weight) and observed improvement in other subjective parameters as well.

\section{REFERENCES}

[1] Sharma R.K. \& Dash B. carak Samhita Sutrasthana 21/4, Choukhamba Sanskrit series varanasi (India), 2004.

[2] Charakasamhitaofagnivesha (part -2), by Dr. BrahmanandTripathi,chaukhambhabharati academy , chp, 10/24 pg.no. 1303. Edition 2012

[3] Sharma R.K. \& Dash B. carak Samhita Sutrasthana, vol. 1, 21/4, Choukhamba Sanskrit series varanasi (India), 2004.

[4] Agnivesha, CharakaSamhita, Ayurveda Deepika Commentary of Chakrapani,edited by; Vaidya YadavjiTrikramji Acharya, ChoukambhaSurabharatiPrakashan, Varanasi, reprint-2011, Sutra Sthana, 23rd Chapter, Verse-6, Pp: 738, pg no-122.

[5] Sri Chakrapanidatta, Chakradatta, and Savimishra 'Vaidyaprabha' Hindi Commentary of Dr IndradevaTripati, edited by; Acharya RamanathDwivedi, Choukambha Sanskrit Samsthana, Varanasi, reprint-2002, 36th Chapter, Verse-31-32-33, Pp: 542, pg no-223.

[6] Mc-grawhill, Harrison's Principal of Internal Medicine Part-1, 2001, Pp: 1442, pg no - 47.

Citation: RITU WADHWA (2019). Case Study of Role of Pippalyadi Basti on Medoroga w.s.r.t. Obesity. International Journal of Medicinal Plants and Natural Products (IJMPNP), 5(4), pp.23-27. http://dx.doi.org/ 10.20431/2454-7999.0504004

Copyright: (1) 2019Authors, this is an open-access article distributed under the terms of the Creative Commons Attribution License, which permits unrestricted use, distribution, and reproduction in any medium, provided the original author and source are credited. 